\section{Antioxidant Capacity and Polyphenolic Compounds of Blackberries Produced in Different Climates}

\author{
Camila P. Croge \\ Federal University of Parana, Curitiba, PR, Brazil
}

Francine L. Cuquel

Department of Agronomy, Federal University of Parana, Curitiba, PR, Brazil

Paula T.M. Pintro

Department of Agronomy, State University of Maringa, Uem. Maringá, PR, Brazil

\author{
Luiz A. Biasi \\ Department of Agronomy, Federal University of Parana, Curitiba, PR, Brazil
}

Claudine M. De Bona

Institute Agronomic of Parana, Curitiba, PR, Brazil

Additional index words. abiotic factors, anthocyanin, Rubus

\begin{abstract}
Antioxidants are compounds with varied chemical structures that are affected by biotic and abiotic factors. The objective of this study was to characterize and compare bioactive compounds and the antioxidant capacity of fruit from four blackberry cultivars produced under different climatic conditions. Ascorbic acid content, total polyphenols, flavonoids, monomeric anthocyanins and antioxidant activity of the fruit were evaluated, and high levels of bioactive compounds as well as antioxidant activity were observed regardless of the cultivar or growing location. The results showed that bioactive production is affected by the cultivar and environment. Furthermore, the antioxidant potential of the blackberry fruit depends on the total phenolics and anthocyanin.
\end{abstract}

Several studies have indicated that the ingestion of natural antioxidants found in fruits and vegetables reduces the damage caused by free radicals and protects the body against many diseases (Schulz et al., 2019; Souza et al., 2014; Van de Velde et al., 2016). However, industrial research is facing the important challenge of substituting synthetic antioxidant compounds for substances derived from plants. Therefore, there is an emphasis on products that fulfill such demands, and it is necessary to find potential sources of such compounds in nature and elucidate the processes related to their production in plants (Croge et al., 2019). Blackberry presents itself as one of the most promising species due to its high level of antioxidant compounds (Moyer et al., 2002). Heinonen et al. (1998) found the highest indices of polyphenols and a higher capacity to inhibit human lowdensity lipoprotein (LDL) degradation (a characteristic related to antioxidant activity)

\footnotetext{
Received for publication 18 July 2019. Accepted for publication 11 Sept. 2019.

We acknowledge IAPAR and UFPR for providing the area, resources, and facilities of the Cerro Azul, Lapa, and Pinhais Experimental Stations, the University State of Maringá for the laboratory structure, and $\mathrm{CNPq}$ for financing.

C.P.C. is the corresponding author. E-mail: Camilacroge@Epagri.Sc.Gov.Br.
}

in blackberries compared with 12 other species of small fruits.

The amount and distribution of antioxidant compounds vary substantially among different blackberry cultivars, as shown by divergent published data regarding the content and classes of compounds found in blackberries (Mullen et al., 2002; ParedesLópez et al., 2010). It is inferred that biotic and abiotic factors such as genetics, climate, water availability, and crop management have an important role in the level of bioactive compounds and antioxidant capacity of blackberries (Castrejón et al., 2008; Reyes-Carmona et al., 2005).

According to Strik (2008), there are more than 20,000 hectares of blackberry worldwide, and there are many cultivars (Campagnolo and Pio, 2012; Clark and Finn, 2011). Some of these were introduced to Brazil in the 1970s, when a breeding program was launched to attend to the demands of some growers. Among them are Tupy, the most widely grown cultivar in South America, and Xavante, a thornless, very promising cultivar in terms of productivity (Croge et al., 2016; Pio and Gonçalves, 2014).

Therefore, the objective of this research was to characterize and compare bioactive compounds and the antioxidant activity of four blackberry cultivars grown under different climates (temperate and humid mesothermal climate).
Tupy, Guarani, Xavante, and Cherokee blackberry cultivars were planted in three municipalities of Parana State in Brazil (Lapa, Pinhais, and Cerro Azul) in 2011. The first two, according to the Koppen climate classification, were planted under a temperate climate $(\mathrm{Cfb})$ and the third was planted under a humid mesothermal climate (Cfa). The Koppen climate classification defines a climate as "temperate" when the mean temperature is higher than $-3{ }^{\circ} \mathrm{C}$ $\left(26.6{ }^{\circ} \mathrm{F}\right)$ but lower than $18{ }^{\circ} \mathrm{C}\left(64.4{ }^{\circ} \mathrm{F}\right)$ during the coldest month. In contrast, the humid subtropical climates have a warm and wet flow from the tropics that creates warm and moist conditions during the summer months. As such, summer is often the wettest season (Fig. 1).

In Lapa, blackberries were dripirrigated with $25 \mathrm{~mm}$ of water per week. Aside from this, the cultural practices were the same for the three areas, with the $\mathrm{pH}$ adjusted to 5.5 and fertilizer based on the recommendation of Naraguma and Clark (1997). A completely randomized experimental design with four replications of six plants per cultivar (both border plants were disregarded) was applied. Plants were conducted on V-shape trellis with three wires on both sides. Fruits were harvested during their physiological maturation stage (Souza et al., 2014). In the laboratory, a completely randomized design with four subdivided parcels was used. Four replications, four cultivars, three locations, and 25 fruits per treatment were used.

The following chemicals, which were obtained from Sigma Aldrich (São Paulo, Brazil), were used in the experiments: 2.2azino-bis(3-ethylbenzthiazoline-6-sulphonic acid) (ABTS); aluminum chloride; catechin; hydrochloric acid; 2.2-diphenyl-1-picrylhydrazyl (DPPH); ethanol; Folin-Ciocalteu reagent; gallic acid; methanol; potassium sulfate; potassium persulfate; sodium carbonate; sodium hydroxide; sulfuric acid; and oxalic acid.

Fruits were stored under refrigeration until extraction and held on the same day of harvest. Juice was extracted with a domestic centrifugal juicer and treated with acidified methanol ( $\mathrm{HCl} 0.01 \%$ ) for phenolic compound (total polyphenols, flavonoids, and anthocyanins) and antioxidant activity analyses.

To determine the ascorbic acid content of the samples, the AOAC International (1992) method was used, but with the standard extraction solution (metaphosphoric acid solution) substituted for oxalic acid solution. To quantify vitamin C, a standard ascorbic acid curve was used. Results were expressed in $\mathrm{mg}$ of ascorbic acid per $100 \mathrm{~g}$ of fresh fruit (FF).

The anthocyanin content was determined by the $\mathrm{pH}$ difference method (Giust and Wrosltad, 2001), whereby the extracts are dissolved in two buffer systems: potassium chloride $\mathrm{pH} 1.0(0.025 \mathrm{M})$ and sodium acetate $\mathrm{pH} 4.5(0.4 \mathrm{M})$. Absorbance of the extracts was measured at 510 and $700 \mathrm{~nm}$. 


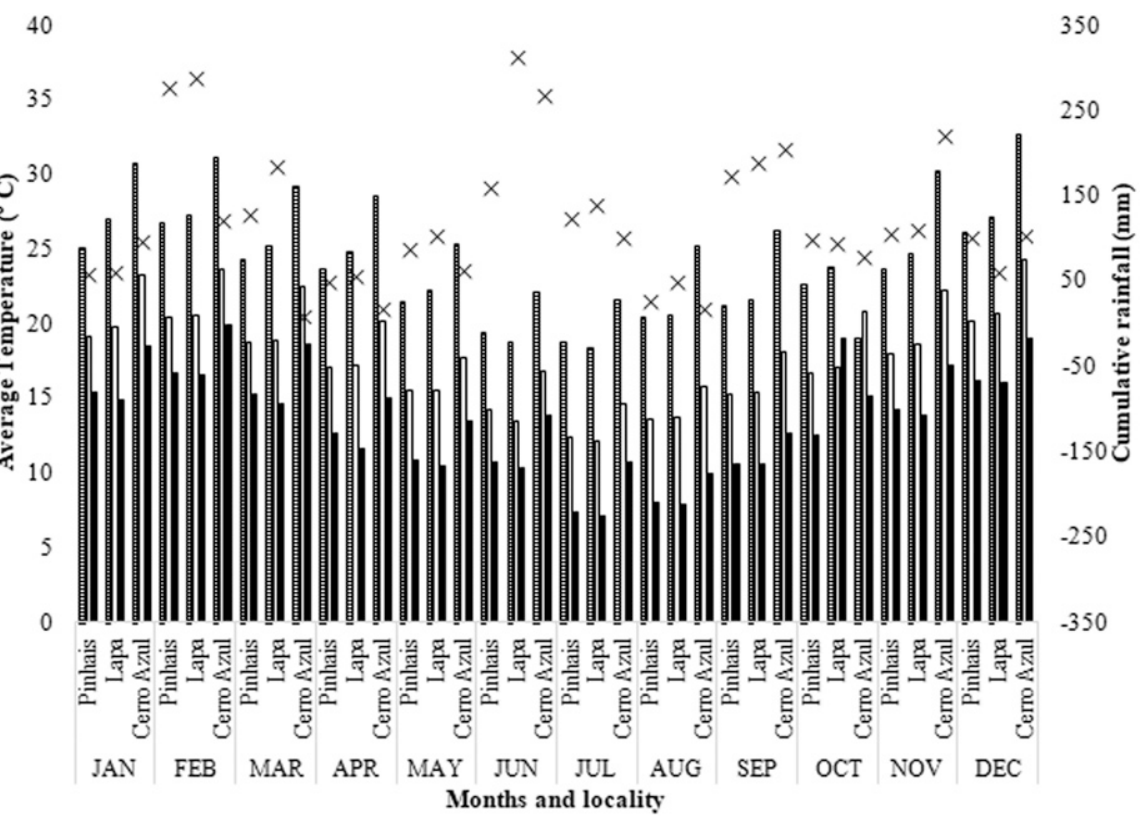

Fig. 1. Monthly minimum, average, and maximum temperatures $\left({ }^{\circ} \mathrm{C}\right)$ and cumulative rainfall $(\mathrm{mm})$ in Pinhais, Lapa, and Cerro Azul in PR. Minimum temperature (black bar); average temperature (white bar); maximum temperature (shaded bar); and cumulative rainfall $(\times)$. Simepar Weather Station data.

Table 1. Contents of ascorbic acid, polyphenols, flavonoids, and monomeric anthocyanins of four blackberry cultivars grown under different climatic conditions.

\begin{tabular}{lccc}
\hline & \multicolumn{2}{c}{ Ascorbic acid $(\mathrm{mg} / 100 \mathrm{~g} \mathrm{FF})$} & Cerro Azul, PR \\
\hline Tupy & Lapa, PR & Pinhais, PR & $25.04 \mathrm{aB}$ \\
Guarani & $21.71 \mathrm{cC}$ & $28.07 \mathrm{aA}$ & $25.15 \mathrm{aB}$ \\
Xavante & $26.65 \mathrm{aA}$ & $23.57 \mathrm{bC}$ & $20.38 \mathrm{cB}$ \\
Cherokee & $23.12 \mathrm{bA}$ & $23.65 \mathrm{bA}$ & $22.57 \mathrm{bC}$ \\
CV location & $25.85 \mathrm{aB}$ & $27.97 \mathrm{aA}$ & \\
& & \\
\hline & & & \\
\hline Tupy & Monomeric anthocyanins & $(\mathrm{mg} / 100 \mathrm{~g} \mathrm{FF})$ & $74.11 \mathrm{cB}$ \\
Guarani & cultivar $=8.47 \%$ & $99.00 \mathrm{abB}$ \\
Xavante & Lapa, PR & $47.55 \mathrm{dC}$ & $123.48 \mathrm{aB}$ \\
Cherokee & $110.73 \mathrm{bcA}$ & $96.06 \mathrm{bB}$ & $82.76 \mathrm{bB}$
\end{tabular}

Total polyphenols (mg GAE/100 g FF)

\begin{tabular}{lccc}
\hline & Lapa, PR & Pinhais, PR & Cerro Azul, PR \\
\hline Tupy & $358.99 \mathrm{bA}$ & $255.00 \mathrm{cB}$ & $231.63 \mathrm{bB}$ \\
Guarani & $370.84 \mathrm{bA}$ & $315.65 \mathrm{bB}$ & $311.59 \mathrm{aB}$ \\
Xavante & $460.65 \mathrm{aA}$ & $374.64 \mathrm{aB}$ & $329.06 \mathrm{aC}$ \\
Cherokee & $346.59 \mathrm{bA}$ & $299.12 \mathrm{bB}$ & $264.61 \mathrm{bC}$
\end{tabular}

$\mathrm{CV}$ location $=10.37 \% / \mathrm{CV}$ cultivar $=11.31 \%$

Flavonoids (mg quercetin/100 g FF)

\begin{tabular}{llcc}
\hline & Lapa, PR & Pinhais, PR & Cerro Azul, PR \\
\hline Tupy & $38.03 \mathrm{bcA}$ & $35.78 \mathrm{bB}$ & $31.36 \mathrm{cC}$ \\
Guarani & $46.29 \mathrm{aA}$ & $36.79 \mathrm{bB}$ & $36.29 \mathrm{bB}$ \\
Xavante & $47.33 \mathrm{aA}$ & $38.16 \mathrm{aBC}$ & $41.87 \mathrm{aB}$ \\
Cherokee & $38.86 \mathrm{bA}$ & $30.44 \mathrm{cB}$ & $33.52 \mathrm{bcB}$
\end{tabular}

$\mathrm{CV}$ location $=8.31 \% / \mathrm{CV}$ cultivar $=10.58 \%$

Monomeric anthocyanins (mg/100 g FF)

\begin{tabular}{lccc}
\hline & Lapa, PR & Pinhais, PR & Cerro Azul, PR \\
\hline Tupy & $110.73 \mathrm{bcA}$ & $47.55 \mathrm{dC}$ & $74.11 \mathrm{cB}$ \\
Guarani & $118.93 \mathrm{bA}$ & $96.06 \mathrm{bB}$ & $99.00 \mathrm{abB}$ \\
Xavante & $134.56 \mathrm{aA}$ & $100.01 \mathrm{aC}$ & $123.48 \mathrm{aB}$ \\
Cherokee & $105.07 \mathrm{cA}$ & $80.08 \mathrm{cB}$ & $82.76 \mathrm{bB}$ \\
Cv location $=9.81 \% /$ cv cultivar $=10.34 \%$ & & \\
\hline
\end{tabular}

Means in the same column followed by the same small or capital letter do not differ significantly $(P \leq$ 0.05 ) according to Tukey's test.
Results were expressed in mg of monomeric anthocyanin per $100 \mathrm{~g}$ of FF.

The total polyphenol content was determined by the Folin and Ciocalteu method, whereby the mix of phosphor wolframic and phospholipid acids in the basic medium reduces itself while oxidizing the phenolic compounds, creating blue wolframic oxides $\left(\mathrm{W}_{8} \mathrm{O}_{23}\right)$ and molybdenum $\left(\mathrm{Mo}_{8} \mathrm{O}_{23}\right)$. Readings were performed in a spectrophotometer at a wavelength of $725 \mathrm{~nm}$ (Moyer et al., 2002). The results were expressed in $\mathrm{mg}$ of gallic acid equivalent (GAE) in $100 \mathrm{~g}$ of $\mathrm{FF}$ using a prepared standard curve with solutions of gallic acid in concentrations ranging from 0 to $600 \mathrm{mg} \cdot \mathrm{L}^{-1}$.

The total flavonoid content in the fruit was quantified by the spectrophotometer method at a wavelength of $425 \mathrm{~nm}$ (Zhishen et al., 1999). The results were expressed in $\mathrm{mg}$ of quercetin per $100 \mathrm{~g}$ of $\mathrm{FF}$ by a standard curve prepared with quercetin solutions in concentrations ranging from 0 to $300 \mathrm{mg} \cdot \mathrm{L}^{-1}$.

One of the methods used to quantify antioxidant activity was the DPPH free radical scavenging method, which was in accordance with the methodology of Brand-Williams et al. (1995) and modifications by Maro et al. (2013). The kinetic reaction between the antioxidants present in the sample and the DPPH radical was registered in three different concentrations to graphically obtain the EC50, i.e., the fresh weight concentration needed to capture $50 \%$ of the radicals initially present in the sample. The absorbance was recorded at $515 \mathrm{~nm}$.

The degradation analysis of the ABTS free radical by the antioxidants present in the sample followed the method proposed by $\mathrm{Re}$ et al. (1999). Absorbance was read in $734 \mathrm{~nm}$ for 7 min and used to estimate the scavenging capacity of the sample free radicals by the following equation: $\%$ of ABTS radical scavenging $=[1-($ Abs $t / A b s$ control $) \times$ 100], where Abs t is the sample absorbance at a given time of the analysis and Abs control is the sample absorbance at time zero.

An analysis of variance (ANOVA) was performed; when variables were significant $(P \leq 0.05)$, the Tukey test was used for multiple comparisons. To visualize the relationship of the chemical properties with the antioxidant capacity of the blackberry fruits, correlation graphs were plotted. SAS (SAS Institute 1999; Cary, NC) and StatSoft, Inc. (2007) software packages were used for the statistical analyses.

\section{Results and Discussion}

Ascorbic acid, total polyphenol, flavonoid, and antochyanin contents are presented in Table 1. A variance analysis showed significant interactions between the cultivar and environment in the production of the blackberry active compounds.

Results showed significant levels of ascorbic acid in in natura blackberry, with an average of $24.5 \mathrm{mg}$ per $100 \mathrm{~g}$ of fruits, i.e., $17 \%$ of the daily recommended intake for humans. However, this fruit cannot be recommended as the only dietary source of this 
Table 2. Antioxidant activity of four blackberry cultivars grown under different climatic conditions (Lapa, Pinhais, and Cerro Azul) found by the DPPH (EC50) and ABTS (\% of radical degradation) methods.

\begin{tabular}{lccc}
\hline & \multicolumn{2}{c}{ EC 50 $(\mathrm{mg}$ of FF/mg DPPH $)$} & Cerro Azul, PR \\
\hline Tupy & Lapa, PR & Pinhais, PR & $2.45 \mathrm{aB}$ \\
Guarani & $1.74 \mathrm{bC}$ & $3.08 \mathrm{aA}$ & $2.17 \mathrm{bA}$ \\
Xavante & $1.74 \mathrm{bB}$ & $2.18 \mathrm{bA}$ & $1.58 \mathrm{cB}$ \\
Cherokee & $0.86 \mathrm{cC}$ & $2.12 \mathrm{bA}$ & $2.19 \mathrm{bB}$ \\
CV location $=6.38 \% /$ cV cultivar $=8.23 \%$ & $2.27 \mathrm{bA}$ & \\
& $1.85 \mathrm{aC}$ & & \\
\hline \multicolumn{2}{c}{ ABTS $(\%$ radical scavenging $)$} & $39.30 \mathrm{bA}$ \\
\hline Tupy & Lapa, PR & Pinhais, PR & $42.00 \mathrm{bB}$ \\
Guarani & $38.14 \mathrm{cA}$ & $36.71 \mathrm{cA}$ & $66.00 \mathrm{aB}$ \\
Xavante & $47.33 \mathrm{bA}$ & $50.51 \mathrm{bA}$ & $46.05 \mathrm{bA}$ \\
Cherokee & $73.38 \mathrm{aA}$ & $57.75 \mathrm{aC}$ & $38.87 \mathrm{cB}$ \\
CV location $=13.42 \% / \mathrm{CV}$ cultivar $=14.23 \%$ & &
\end{tabular}

Means in the same column followed by the same small or capital letter do not differ significantly $(P \leq$ 0.05 ) according to Tukey's test.

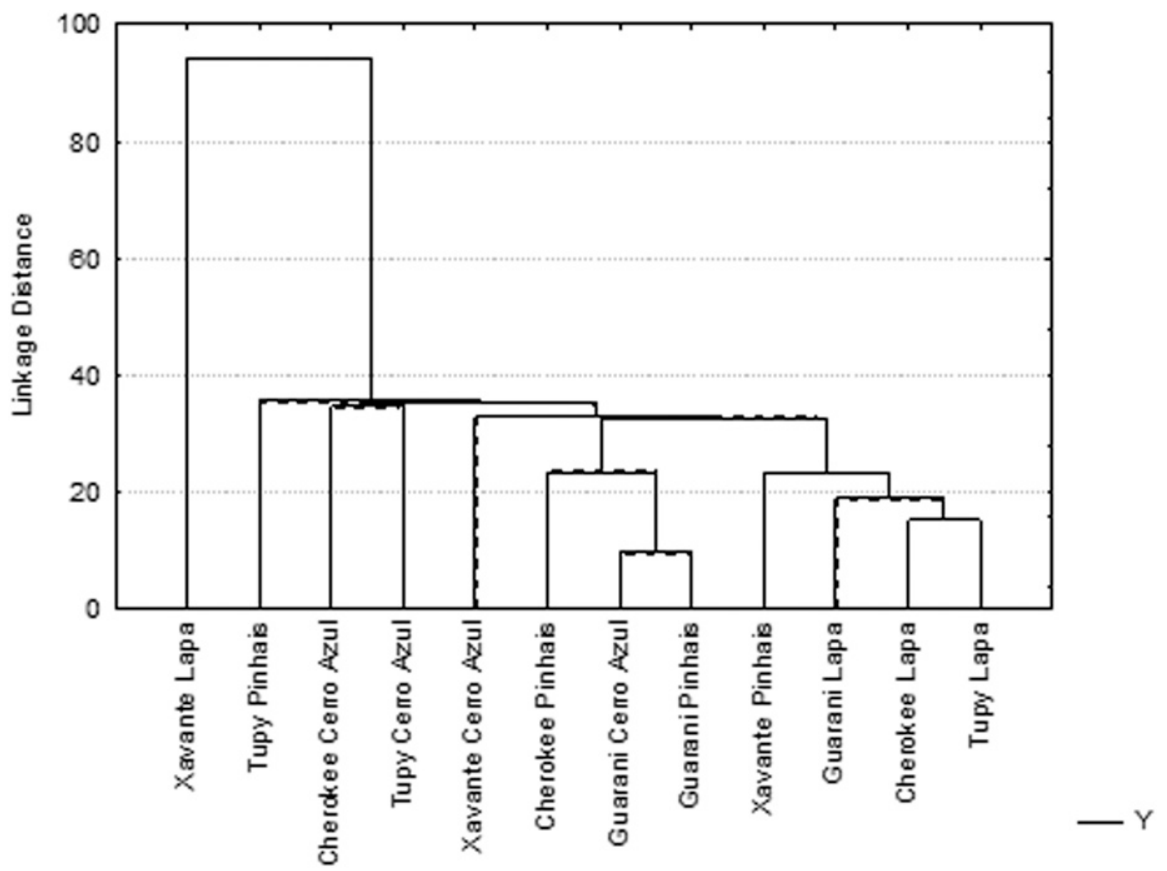

Fig. 2. Dendrogram showing the relationship of cultivars and growing locations with the bioactive composition of the fruits (Euclidean distance).

Table 3. Average Euclidean distance estimates of blackberry cultivar dissimilarities.

\begin{tabular}{|c|c|c|c|c|c|c|c|c|c|c|c|c|c|}
\hline & & \multicolumn{3}{|c|}{ Tupy } & \multicolumn{4}{|c|}{ Guarani } & \multicolumn{3}{|c|}{ Xavante } & \multicolumn{2}{|c|}{ Cherokee } \\
\hline & & $\mathrm{L}$ & $\mathrm{P}$ & $\mathrm{C}$ & $\mathrm{L}$ & $\mathrm{P}$ & $\mathrm{C}$ & $\mathrm{L}$ & $\mathrm{P}$ & $\mathrm{C}$ & $\mathrm{L}$ & $\mathrm{P}$ & $\mathrm{C}$ \\
\hline \multirow[t]{3}{*}{ Tupy } & $\mathrm{L}$ & 0 & 122 & 133 & 19 & 47 & 49 & 111 & 27 & 43 & 15 & 68 & 99 \\
\hline & $\mathrm{P}$ & & 0 & 36 & 137 & 79 & 77 & 227 & 132 & 110 & 109 & 55 & 38 \\
\hline & $\mathrm{C}$ & & & 0 & 147 & 88 & 84 & 240 & 147 & 113 & 119 & 68 & 35 \\
\hline \multirow[t]{3}{*}{ Guarani } & $\mathrm{L}$ & & & & 0 & 61 & 64 & 95 & 23 & 46 & 29 & 84 & 113 \\
\hline & $\mathrm{P}$ & & & & & 0 & 10 & 152 & 60 & 35 & 33 & 27 & 53 \\
\hline & $\mathrm{C}$ & & & & & & 0 & 157 & 65 & 39 & 36 & 24 & 50 \\
\hline \multirow[t]{3}{*}{ Xavante } & $\mathrm{L}$ & & & & & & & 0 & 94 & 132 & 121 & 175 & 205 \\
\hline & $\mathrm{P}$ & & & & & & & & 0 & 52 & 31 & 81 & 112 \\
\hline & $\mathrm{C}$ & & & & & & & & & 0 & 33 & 60 & 79 \\
\hline \multirow[t]{3}{*}{ Cherokee } & $\mathrm{L}$ & & & & & & & & & & 0 & 55 & 85 \\
\hline & $\mathrm{P}$ & & & & & & & & & & & 0 & 35 \\
\hline & $\mathrm{C}$ & & & & & & & & & & & & 0 \\
\hline
\end{tabular}

$\mathrm{L}=$ Lapa, PR; $\mathrm{P}=$ Pinhais, $\mathrm{PR} ; \mathrm{C}=$ Cerro Azul, $\mathrm{PR}$.

vitamin. Souza et al. (2014) found higher levels of ascorbic acid in strawberries and blueberries (90.1 and $73.2 \mathrm{mg}$ per $100 \mathrm{~g}$ of $\mathrm{FF}$, respectively).

Ascorbic acid is a hydrosoluble vitamin that is easily oxidized by heat, light, and oxygen. Under humid subtropical conditions, there are higher temperatures, which may have contributed to the degradation of this vitamin in the fruits. There were variations among cultivars and growing locations; however, no observed pattern was able to indicate which cultivars and locations were better for ascorbic acid production. The levels varied from 20.4 to $28.1 \mathrm{mg} / 100 \mathrm{~g}$ of FF. Pantelidis et al. (2007) found great variations in the levels of vitamin $\mathrm{C}$ in different Rubus cultivars (14.3 and $103.3 \mathrm{mg} / 100 \mathrm{~g}$ of FF). Deighton et al. (2000) found values between 12.3 and 16.4 $\mathrm{mg} / 100 \mathrm{~g} \mathrm{FF}$ in wild blackberry species.

In Table 1, variations in total polyphenol concentrations according to climate and cultivar are shown. Moyer et al. (2002) found values of 275 to $678 \mathrm{mg}$ of GAE/100 $\mathrm{g} \mathrm{FF}$ in a group of 27 blackberry hybrids. The values found herein were higher than those found in strawberries (Isabelle et al., 2010; Kuskoski et al., 2006). Souza et al. (2014) also found higher levels of total polyphenols in blackberry compared with other small fruits, such as strawberry and raspberry, grown under tropical conditions. It was observed that fruits harvested in Lapa, PR (temperate climate, under irrigation), presented higher levels of total polyphenols (Table 1). Conversely, the humid mesothermal climate of Cerro Azul, PR, induced lower production of these compounds. Chemically, total polyphenols are synthesized mainly through the shikimate pathway in plants, and the main enzyme is the ammonium phenylalanine lyase (PAL). The action of this enzyme is regulated by environmental factors such as temperature and water availably (Cechinel-Filho, 2012; Manach et al., 2004), which explains the differences found in the fruits from the three locations.

Hydric stress promotes significant consequences for the concentration of secondary metabolites in plants. Many reports have inferred that such conditions increase the compound composition. However, regarding phenolic metabolites, these studies present conflicting results (Dustin and CooperDriver, 1992; Tattini et al., 2004). It is possible that the effect of drought on the concentrations of these metabolites is dependent on stress levels and the physiological development period of occurrence, with short periods related to greater productivity and long periods related to less productivity. Furthermore, the irregularity of rain distribution throughout the year may have caused a reduction in the polyphenol production of blackberry grown in Pinhais and Cerro Azul, which were not irrigated (Fig. 1).

Regarding temperature, a positive correlation between the intensity and duration of cold and mRNA producers of key enzymes of the shikimic acid pathway, such as PAL, has been reported (Cechinel-Filho, 2012). Therefore, the temperate climate in Lapa and Pinhais, because these areas present more rigorous winters, had a positive effect on polyphenol production (Fig. 1).

The Xavante cultivar presented higher total polyphenol production in its fruits (Table 1). This cultivar stands out because of its thornless stems, which is a recessive trait. However, its greater acidity of fruits is also a characteristic of this cultivar (Croge et al., 2016; Croge et al., 2019). This high acidity occurs due to a greater amount of tannins, which are also classified as 

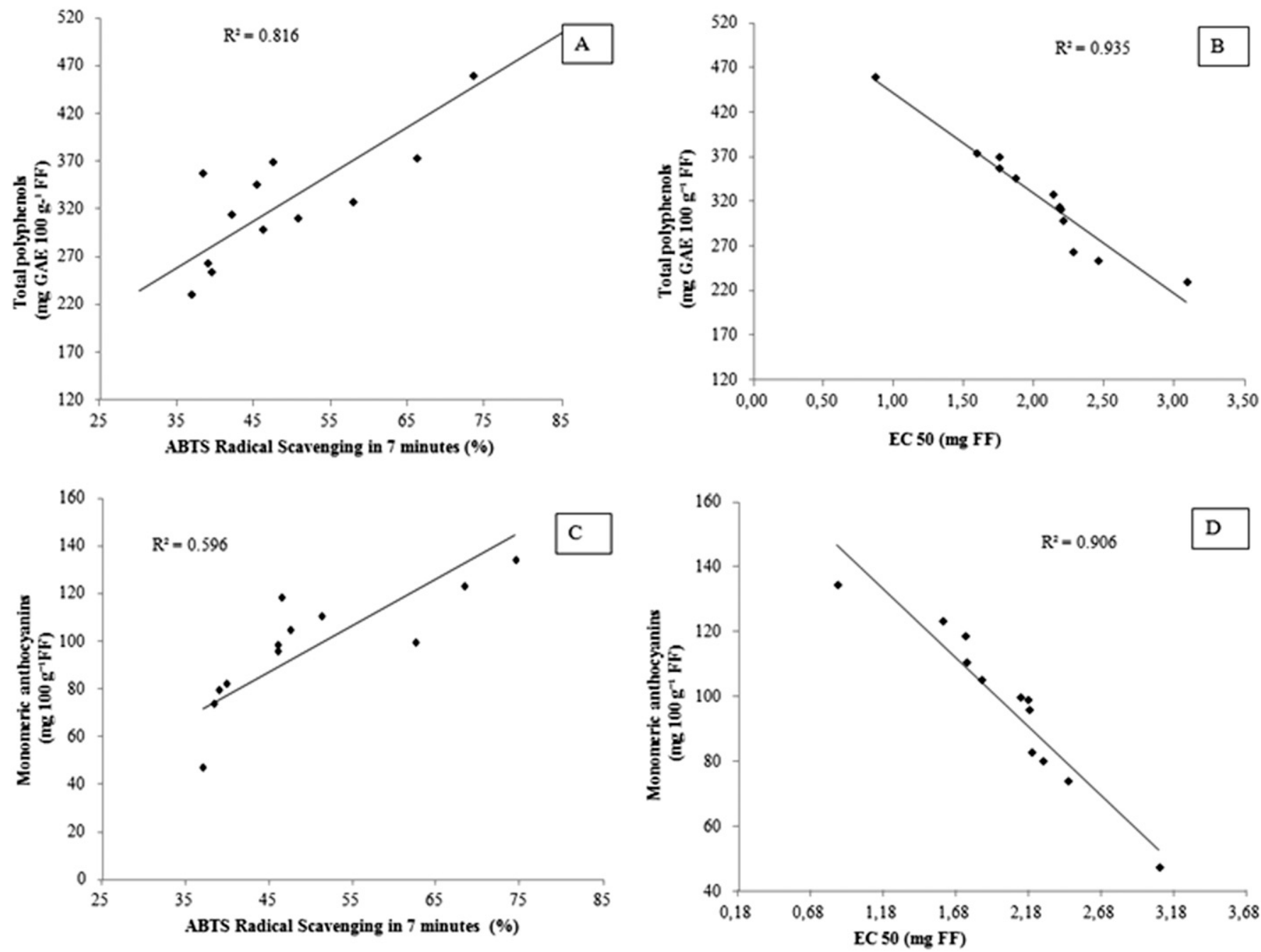

Fig. 3. Correlations between the bioactive compounds and antioxidant activity of blackberry fruits. (A) Total polyphenol content and antioxidant activity found by the ABTS method. (B) Total polyphenol content and antioxidant activity found by the DPPH method. (C) Monomeric anthocyanins and antioxidant activity found by DPPH. (D) Ascorbic acid and antioxidant activity found by ABTS.

polyphenols. Hence, the higher contents found in this cultivar are justifiable (Croge et al., 2016; Fennema et al., 2010; Poling, 1996).

Fruits harvested in Lapa, PR, and from Xavante also presented higher concentrations of flavonoids and anthocyanins (Table 1). This is probably because flavonoids and anthocyanins are also shikimate pathway derivatives and dependent on PAL because they are a specific class of phenolic compound.

Regarding flavonoids, the average of $38.8 \mathrm{mg}$ of quercetin obtained in $100 \mathrm{~g}$ of blackberry is considered high. Manach et al. (2004) reported that flavonoid levels are usually low in food (from 1.5 to $3.0 \mathrm{mg}$ of quercetin per $100 \mathrm{~g}$ of $\mathrm{FF}$ ), and that one of the richest sources of such compounds was blueberry, with concentrations ranging from 3 to $16 \mathrm{mg}$ of quercetin per $100 \mathrm{~g}$ of FF. The concentrations in the blackberries analyzed herein exceeded those concentrations, suggesting that they are rich sources of these compounds. Souza et al. (2014) found flavonoid levels 1.8-times higher in blackberries than in blueberries. Studies have indicated that a diet rich in flavonoids may protect the body against cardiovascular diseases, neurodegenerative disorders, and some types of cancer (Fennema et al., 2010; Paredes-López et al., 2010).

The anthocyanin values found in blackberries were also high and exceeded the values described for other small fruits in the literature, thus emphasizing the great potential of blackberry fruits as natural color additives in the food, drug, and cosmetic industries (Table 1). Souza et al. (2014) found levels of $9.6,38.2$, and $47.5 \mathrm{mg} / 100$ $\mathrm{g}$ of FF in raspberry, strawberry, and blueberry, respectively. Kuskoski et al. (2006) found $23.7 \mathrm{mg} / 100 \mathrm{~g}$ of FF in strawberry.

One of the most described properties of anthocyanin is its antioxidant activity (Martínez-Flórez et al., 2002; Nijveldt et al., 2001). Such activity may be confirmed by the high degradation level of ABTS radicals and low EC50 levels observed in blackberry fruits (Table 2).

The EC50 values were various and were lower in Xavante (i.e., fewer fruits are needed to degrade $50 \%$ of the free radicals) (Table 2). Furthermore, fruits from Lapa, PR, presented even higher antioxidant potential (lower EC50). However, even the lowest values indicated the higher antioxidant potential of blackberries compared with strawberries, raspberries, and blueberries (Souza et al., 2014).

Based on the degradation level of the ABTS free radical, Xavante presented the highest antioxidant potential (Table 2), and Tupy presented the lowest. Antioxidant activity measured by the ABTS method was similar in Tupy and Guarani cultivars from Lapa and Pinhais and different in Xavante and Cherokee cultivars. The temperate climate was more adequate for the production of antioxidant compounds than the humid mesothermal climate.

Souza et al. (2014) found that blackberries analyzed by ABTS present higher antioxidant concentrations than other small fruits, such as blueberries and strawberries. Therefore, this research has shown that blackberries are a good source of antioxidants and have potential use in various industries, especially Xavante fruits. 
Similarities among samples were evaluated using a hierarchical cluster analysis and $\mathrm{Eu}-$ clidean distances (Fig. 2, Table 3). The greatest divergence in the bioactive composition of fruits appeared between 'Xavante' from Lapa and 'Tupy' from Cerro Azul, followed by 'Tupy' from Pinhais. This further highlights the superiority of 'Xavante' and the influence of the agronomical conditions of Lapa in the bioactive composition of the fruits.

The antioxidant activity of blackberries had a positive correlation with the monomeric anthocyanin and polyphenol contents (Fig. 3). A higher correlation was detected between the polyphenol content and antioxidant activity by the DPPH method $\left(R^{2}=\right.$ $0.935)$. The total polyphenol content was negatively correlated to EC50 values; hence, it was positively correlated to the antioxidant potential.

A high correlation was also perceived between the total polyphenol content and ABTS degradation $\left(R^{2}=0.816\right)$ and the monomeric anthocyanin content EC50 $\left(R^{2}=\right.$ 0.906 ). A positive correlation was also observed between monomeric anthocyanin and ABTS radical degradation. These data indicated that the total polyphenol content is responsible for the antioxidant potential of blackberry fruits, and that the higher the concentration of such compounds in the fruits, the better this potential will be.

\section{Conclusion}

Blackberry fruits are rich sources of phenolic compounds (total polyphenols, flavonoids, and anthocyanins) and have the potential to be used in industry as natural sources of such compounds. Levels of bioactive compounds and antioxidant activity of blackberry fruits are dependent on the cultivar and the climatic conditions of the growing location. Among the studied cultivars, Xavante has the greatest potential for industrial use. Furthermore, the plants are thornless, which facilitates cultural practices. A temperate climate allied with irrigation provided a better environment for the production of bioactive compounds in the blackberry cultivars studied. There was a high correlation between the bioactive compounds concentration and the antioxidant activity of the studied blackberry cultivars.

\section{Literature Cited}

Association of Official Agricultural Chemists (AOAC) International. 1992. Official methods of analysis of the Association of Official Analytical Chemistry. 11th ed. AOAC International, Washington, DC. p. 1115.

Brand-Williams, W., M.E. Cuvelier, and C. Berset. 1995. Use of a free radical method to evaluate antioxidant activity. Food Sci. Technol. (Campinas) 28:25-30.
Campagnolo, M.A. and R. Pio. 2012. Phenological and yield performance of black and redberry cultivars in western Paraná state. Acta Sci. Agron. 34:439-444.

Castrejón, A.D.R., I. Eichholz, S. Rohn, L.W. Kroh, and S. Huyskens-Keil. 2008. Phenolic profile and antioxidant activity of highbush blueberry (Vaccinium corymbosum L.) during fruit maturation and ripening. Food Chem. 109:564-572.

Cechinel-Filho, V. 2012. Plant Bioactives and Drug Discovery: Principles, Practice, and Perspectives. 1st ed. Wiley, Hoboken, NJ.

Clark, J.R. and C.E. Finn. 2011. Blackberry breeding and genetics. Fruit Veg Cereal Sci Biotech 5:27-43.

Croge, C.P., F.L. Cuquel, L.A. Biasi, and C. De Bona. 2016. Performance of blackberry cultivars in Cerro Azul - PR. Rev. Bras. Frutic. 38(e-141).

Croge, C.P., F.L. Cuquel, L.A. Biasi, C. De Bona, and P.T.M. Pintro. 2019. Agronomic performance of Blackberry cultivars in Lapa-PR Rev. Bras. Frutic. 41(e-101).

Deighton, N., R. Brennan, C. Finn, and H.V Davies. 2000. Antioxidant properties of domesticated and wild Rubus species. J. Sci. Food Agr. 80:1307-1313.

Dustin, C.D. and G.A. Cooper-Driver. 1992. Changes in phenolic production in the hayscented fern (Dennstaedtia punctilobula) in relation to resource availability. Biochem. Syst. Ecol. 20:99-106.

Fennema, O.R., S. Damodaran, and K. Parkin. 2010. Fennema's food chemistry. 4th ed. Artmed, London, New York.

Giust, M. M.; and Wrosltad, R. E. 2001. Characterization and measurement of anthocyanins by UV-visible spectroscopy. Curr. Protoc. Food Anal. Chem. F:F1:F1.2.

Heinonen, M., P.J. Lehtonen, and A.I. Hopia. 1998. Antioxidant activity of berry and fruit wines and liquors. J. Sci. Food Agr. 46:25-31.

Isabelle, M., B.L. Lee, M.T. Lim, W. Koh, D. Huang, and C.N. Ong. 2010. Antioxidant activity and profiles of common fruits in Singapore. Food Chem. 123:77-84.

Kuskoski, E.M., A.G. Asuero, M.T. Morales, and R. Fett. 2006. Frutos tropicais silvestres e polpas de frutas congeladas: Atividade antioxidante, polifenóis e antocianinas. Cienc. Rural 36:1283-1287.

Manach, C., A. Scalbert, C. Morand, C. Remesy, and L. Jimenez. 2004. Polyphenols: Food sources and bioavailability. Am. J. Clin. Nutr. 79:727-747

Maro, L.A.C., R. Pio, M.N.S. Guedes, C.M.P. Abreu, and P.N. Curi. 2013. Bioactive compounds, antioxidant activity and mineral composition of fruits of raspberry cultivars grown in subtropical areas in Brazil. Fruits 68:209217.

Martínez-Flórez, S., J. González-Gallego, J.M. Culebras, and M.J. Tuñón. 2002. Los flavonóides: Propiedades y acciones antioxidantes. Nutr. Hosp. 6:271-278.

Moyer, R.A., K.E. Hummer, C.E. Finn, B. Frei, and R.E. Wrolstad. 2002. Anthocyanins, phenolics, and Antioxidants capacity in diverse small fruits: Vaccinium, Rubus, and Ribes. J. Agr. Food Chem. 50:519-525.

Mullen, W., A.J. Stewart, M.E.J. Lean, P. Gardner, G.C. Duthie, and A. Crozier. 2002. Anthocyanins, phenolics, and antioxidant capacity in diverse small fruits: Vaccinum, Rubus, and Ribes. J. Agr. Food Chem. 50:5197-5201.

Naraguma, J. and R. Clark. 1997. Effect of N fertilization on Arapaho thornless blackberry. HortScience 32:596.

Nijveldt, R.J., E. Van Nood, H. Van, P.G. Boelens, K. Van Norren, and P.A. Van Leeuwen. 2001. Flavonoids: A review of probable mechanisms of action and potential applications. Am. J. Clin. Nutr. 4:418-425.

Pantelidis, G.E., M. Vasilakakis, G.A. Manganaris, and G. Diamantidis. 2007. Antioxidant capacity, phenol, anthocyanin and ascorbic acid contents in raspberries, blackberries, red currants, gooseberries and Cornelian cherries. Food Chem. 102:777-783.

Paredes-López, O., M.L. Cervantes-Ceja, M. Vigna-Pérez, and T. Hérnandez-Pérez. 2010. Berries: Improving human health and healthy aging, and promoting quality - A review. Plant Foods Hum. Nutr. 65:299-308.

Pio, R. and E.D. Gonçalves. 2014. Cultivo da amoreira preta, p. 186-221. In: R. Pio (ed.). Cultivo de fruteiras de clima temperado em regiões subtropicais e tropicais. 1st ed. UFLA, Lavras.

Poling, E.B. 1996. Blackberries. J. Small Fruit Vitic. 14:38-69.

Re, R., N. Pellegrini, A. Proteggente, A. Pannala, M. Yang, and C. Rice-Evans. 1999. Antioxidant activity applying an improved ABTS radical cation decolorization assay. Free Radic. Biol. Med. 26:1231-1237.

Reyes-Carmona, J., G.G. Yousef, R.A. MartinezPeniche, and M.A. Lila. 2005. Antioxidant capacity of fruit extracts of Bblackberry (Rubus sp.) produced in different climatic regions. J. Food Sci. 70:497-503.

Schulz, M., S.K.T. Seraglio, F.B. Betta, P. Nehring, A.C. Valese, H. Daguer, L.V. Gonzaga, A.C.O. Costa, and R. Fett. 2019. Blackberry (Rubus ulmifolius Schott): Chemical composition, phenolic compounds and antioxidant capacity in two edible stages. Food Res. Int. 122:627-634

Souza, V.R., P.A.P. Pereira, T.L.T. Silva, L.C.O Lima, R. Pio, and F. Queiroz. 2014. Determination of the bioactive compounds, antioxidant activity and chemical composition of Brazilian blackberry, red raspberry, strawberry, blueberry and sweet cherry fruits. Food Chem. 156:362368.

Strik, B. 2008. Worldwide production of blackberries. Acta Hort. 777:209-218.

StatSoft, Inc. 2007. STATISTICA (data analysis software system), version 8.0. Dec. 2015. $<$ www.statsoft.com $>$.

Tattini, M., C. Galardi, P. Pinelli, R. Massai, D. Remorini, and G. Agati. 2004. Differential accumulation of flavonoids and hydroxycinnamates in leaves of Ligustrum vulgare under excess light and drought stress. New Phytol. 163:547-561.

Van de Velde, F., M.H. Grace, D. Esposito, M.É. Pirovani, and M.A. Lila. 2016. Quantitative comparison of phytochemical profile, antioxidant, and anti-inflammatory properties of blackberry fruits adapted to Argentina. J. Food Compos. Anal. 47:82-91.

Zhishen, J., T. Mengcheng, and W. Jianming. 1999. The determination of flavonoid contents in mulberry and their scavenging effects on superoxide radicals. Food Chem. $64: 555-559$. 